\title{
("twing
}

\section{LITERATURA E JORNALISMO NO OITOCENTOS: O DISCURSO DA POETISA NARCISA AMÁLIA EM FAVOR DA INSTRUÇÃO INTELECTUAL DA MULHER NO SEMANÁRIO O SEXO FEMININO}

\author{
Nataly Rafaele Ternero ${ }^{1}$ \\ Universidade Federal de Alfenas, Minas Gerais. PIBIC/CNPq. \\ (natalyrafaelle23@gmail.com) \\ Aparecida Maria Nunes ${ }^{2}$ \\ Universidade Federal de Alfenas, Minas Gerais. \\ (cydamaria@gmail.com)
}

\begin{abstract}
Resumo: O presente artigo se propõe a contextualizar o cenário político-cultural brasileiro nos anos de 1800, analisando a contribuição das mulheres intelectuais da época para a literatura e, em especial, para a imprensa. Como ponto principal de discussão e análise, utilizou-se a produção da poetisa Narcisa Amália de Campos na folha feminina O sexo feminino, comandada pela professora e jornalista Francisca Senhorinha da Motta Diniz.

Palavras-chave: imprensa feminina; Oitocentos; Narcisa Amália.

\section{LITERATURE AND JOURNALISM IN THE NINETEENTH CENTURY: THE SPEECH OF THE POET NARCISA AMÁLIA IN FAVOR OF THE INTELLECTUAL INSTRUCTION OF WOMEN IN THE WEEKLY O SEXO FEMININO}

Abstract: This article aims to contextualize the Brazilian political and cultural scene in the 1800 s, analyzing the contribution of intellectual women of that time to literature, especially to the press. As the main point of discussion and analysis, the utilized source was the poetess Narcisa Amália de Campos' production in the feminine newspaper The female sex, commanded by professor and journalist Francisca Senhorinha da Motta Diniz.

Keywords: Women's press; XIX century; Narcisa Amália.

\section{LITERATURA Y PERIODISMO EN EL SIGLO XIX: EL DISCURSO DE LA POETISA NARCISA AMÁLIA A FAVOR DE LA INSTRUCCIÓN INTELECTUAL DE LAS MUJERES EN EL SEMANARIO O SEXO FEMENINO}

Resumen: Este artículo propone contextualizar el escenario político-cultural brasileño en el siglo XIX, analizando la contribución de las mujeres intelectuales de la época a la literatura y especialmente a la prensa. Como punto principal de discusión y análisis, se utilizó la producción de la poeta Narcisa

\footnotetext{
${ }^{1}$ Licenciada em Letras - Português pela Universidade Federal de Alfenas, Minas Gerais. Bolsista do projeto de iniciação científica Literatura e jornalismo no Oitocentos: o discurso da poetisa Narcisa Amália em favor da instrução intelectual da mulher no semanário $O$ sexo feminino, financiado pela agência de fomento à pesquisa PIBIC/CNPq no período de agosto de 2016 a julho de 2017.

2 Pós-doutora em Estudos Literários pela Universidade Federal de Minas Gerais; professora do curso de Letras e do mestrado em História Ibérica da Universidade Federal de Alfenas, Minas Gerais; orientadora do projeto de iniciação científica Literatura e jornalismo no Oitocentos: o discurso da poetisa Narcisa Amália em favor da instrução intelectual da mulher no semanário O sexo feminino.
} 


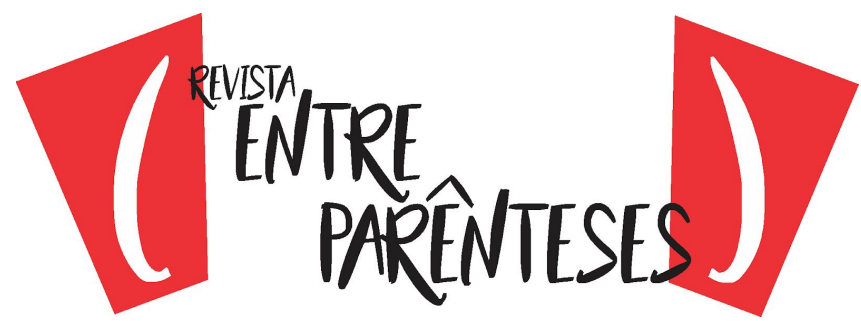

Amália de Campos en el periódico de mujeres: El sexo femenino, dirigida por la maestra y periodista Francisca Senhorinha da Motta Diniz.

Palabras clave: prensa de mujeres; Ochocientos; Narcisa Amália.

\section{Introdução}

Com o avanço das pesquisas tanto na área literária, quanto na histórica, percebe-se a necessidade de revisitar e recontar a memória e as contribuições das mulheres nos mais diversos âmbitos. Muitas de suas histórias permanecem soterradas e inexploradas em um passado dominado pela visão predominantemente masculina dos acontecimentos.

Pensar e pesquisar as mulheres do passado, que em muitos casos não obtiveram reconhecimento por seus feitos e obras em vida, é essencial para compreender diversos fatores e dinâmicas da sociedade da época, refletindo, também, sobre a realidade atual.

As mulheres contribuíram grandemente com seus escritos, tanto na literatura como na imprensa, às vezes expondo seus próprios nomes e rostos, outras sob pseudônimos, mas não menos pioneiras. É interessante e necessário refletir sobre as condições materiais e simbólicas nas quais essas mulheres se encontravam: materiais porque eram quase em sua totalidade financeiramente dependentes de algum homem, seja pai, marido ou irmão; simbólicas porque não se entendiam (nem eram reconhecidas) como indivíduos que poderiam arriscar-se, ocupando posições de destaque e contrariando discursos intelectuais masculinos.

Durante muito tempo, pintou-se a imagem das mulheres do passado como senhoras complacentes, recatadas e tímidas; mas, a cada revisão histórica feita, adentrando antigos arquivos e livros, dá-se conta de muitos atos de subversão feminina que passaram despercebidos e foram ignorados por grande parte da população. 


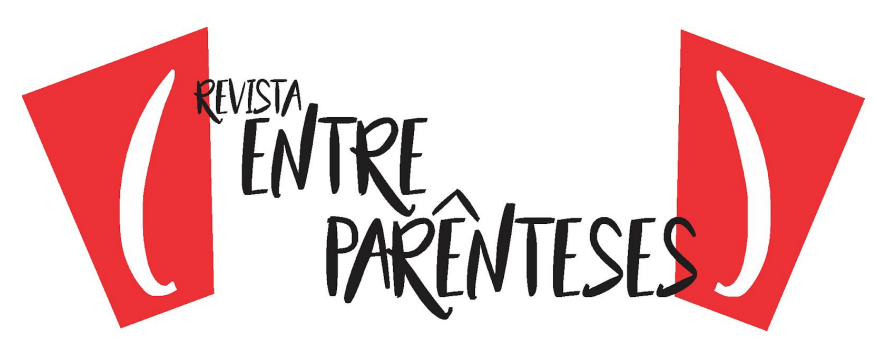

A colonização do Brasil foi fruto de violência masculina; aprisionamento, escravidão e estupro foram as armas do homem branco português. Como a pesquisadora Norma Telles relembra em seu texto Rebeldes, escritoras, abolicionistas, os homens procuravam com frequência as mulheres índias e negras, violando-as, o que era visto como parte dos costumes da época, importante para manter intacta a esposa branca, que era "fiel, tarefeira, assexuada, ignorante e trancada em casa" (TELLES, 2016, p. 2).

Além disso, as mulheres eram impedidas e desencorajadas a pensar plena e independentemente, não recebendo o devido acesso à educação e o estímulo de suas inteligências. Ser uma escritora, nesse contexto, exigia rebeldia e desobediência.

Dentre a pouca literatura abolicionista que o país possui, há alguns escritos femininos que raramente são mencionados nas antologias que tratam sobre essa temática. Norma Telles afirma que muito ganharia a cultura literária brasileira se essas mulheres escritoras fossem lembradas e divulgadas. Pode-se citar 0 exemplo - relembrado pela pesquisadora - de Maria Firmina dos Reis, professora e autora do livro Úrsula, de 1859 , considerado o primeiro romance brasileiro escrito por uma mulher, e do conto A escrava, de 1887. Em suas obras, defendia o direito dos escravos, usava um vocabulário "digno e distinto" para descrever suas personagens e narrava as injustiças da época. Recebeu pouco ou nenhum reconhecimento por estes pioneiros escritos.

Dez anos depois da publicação de Úrsula, entretanto, o escritor Joaquim Manuel de Macedo ficou muito conhecido por seu As vítimas-algozes, com temática parecida, colocando, porém, os escravos em posição de "cobras" e os senhores brancos como indefesos e bons. Esse fato nos revela o quanto a literatura feminina é escondida e desconsiderada, mesmo que seja pioneira e inovadora.

$\mathrm{O}$ direito à educação, sempre negado às mulheres, aparece como uma pauta a ser reivindicada abertamente em páginas dos jornal femininos, em tom 


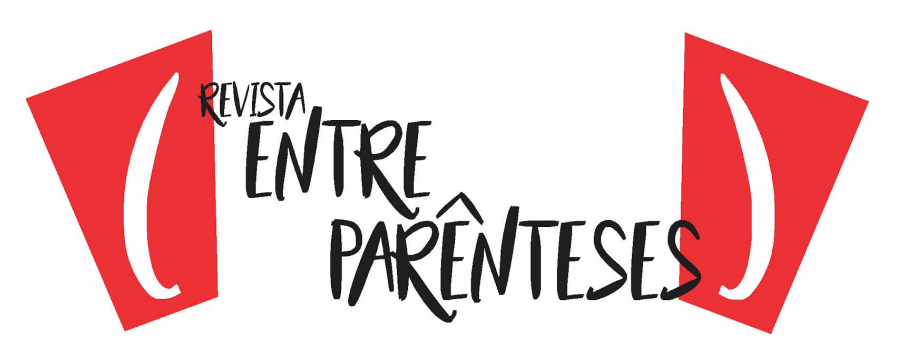

combativo e encorajador. Querendo mais do que um ensino que as preparasse para os serviços do lar, essas mulheres pesquisavam, traduziam e produziam artigos que eram publicados nestas páginas femininas e, pode-se dizer, feministas.

Essas jornalistas e escritoras empenhavam-se muito em manter-se atualizadas sobre a situação dos direitos civis das mulheres ao redor do mundo. Assim, era comum que lessem muito material estrangeiro, traduzindo-os e, às vezes, readaptando-os para a realidade brasileira, como cita Eliane Vasconcellos em seu artigo A imprensa feminina: "Na deglutinação geral das ideias estrangeiras, era praxe promover-se uma acomodação de tais ideias ao cenário nacional." (VASCONCELLOS, 2006, p. 2). Para ilustrar esse movimento de leituras e pesquisas feitas pelas jornalistas, a pesquisadora destaca a seguinte fala de Nísia Floresta Brasileira Augusta (1810 - 1885), um dos principais nomes da imprensa feminina do Oitocentos:

Povos do Brasil, que vos dizeis civilizados! Governo, que vos dizeis liberal! Onde está a doação mais importante dessa civilização, desse liberalismo? Em todos os tempos, e em todas as nações do mundo, a educação da mulher foi sempre a das mais salientes características da civilização dos povos. (AUGUSTA apud VASCONCELLOS, 2006, p. 90).

Alguns fatores se mostraram empecilhos para a livre distribuição de exemplares das páginas femininas. A sociedade oitocentista era composta majoritariamente por analfabetos, o que restringia grandemente o número de leitores dessas publicações. O ensino para as mulheres era voltado aos afazeres do lar e à manutenção do casamento e da família, o que dificultava a aprendizagem de como escrever diferentes gêneros e do funcionamento de um jornal.

Era, também, difícil para as mulheres ter sua própria fonte de renda, sem depender de nenhum homem, seja pai, marido ou irmão, o que restringia as possibilidades de ação de uma senhora na sociedade, como a de ter seu próprio negócio. É importante lembrar que a esfera pública era exclusiva dos homens, e as 


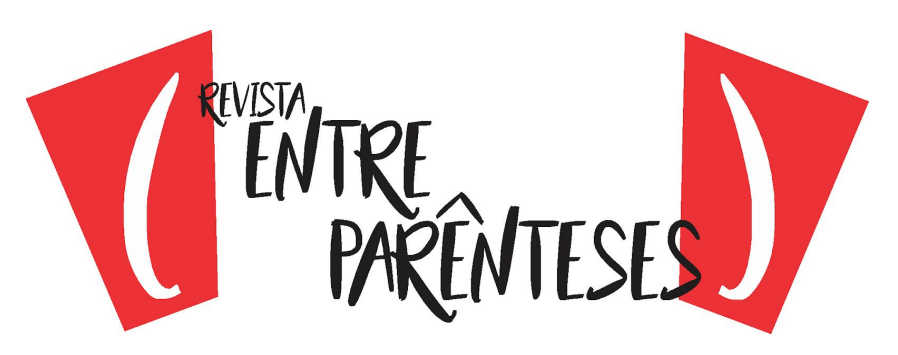

mulheres que nela adentravam eram mal vistas pela sociedade, o que dificultava a criação e divulgação de seus trabalhos.

Haviam algumas folhas dedicadas à mulher e à família, mas até então todas eram escritas e dirigidas por homens, que às vezes assumiam pseudônimos femininos, para conferir maior verossimilhança a seus escritos, que consistiam em dicas para o lar, receitas culinárias e artigos de moda. Segundo Gerlice Rosa no artigo A mulher projetada no discurso: a construção ethótica de Senhorinha Diniz em $O$ sexo feminino:

As mulheres foram, então, conquistando espaço também como produtoras no mundo das letras, inicialmente como colaboradoras dos jornais escritos pelos homens e, a partir de 1823, assinando elas mesmas as produções no lançamento de jornais femininos, escritos e direcionados para mulheres. (ROSA, 2011, p. 133).

O Rio de Janeiro, por ser a capital do país naquela época, era o lugar no qual os trabalhadores da imprensa tinham um pouco mais de facilidade em consolidarem-se e divulgar seus produtos. "O primeiro periódico escrito por e para as mulheres no Brasil foi o Jornal das Senhoras, fundado em 1852 por Joana Paulo Manso de Noronha." (NETO, 2015).

O direito à educação e ao voto constituíam as grandes pautas dos periódicos feministas entre o século XIX e XX. A imprensa em Minas Gerais era mais conservadora, não sendo tão politicamente ativa. Neste contexto, algumas mulheres se destacaram por utilizarem-se da imprensa como arma contra as opressões diárias que viviam. É o caso da poetisa Narcisa Amália de Campos no jornal $\mathbf{O}$ sexo feminino, organizado e publicado pela jornalista e professora Francisca Senhorinha da Motta Diniz.

\section{O sexo feminino, construção de Francisca Senhorinha e suas colaboradoras}




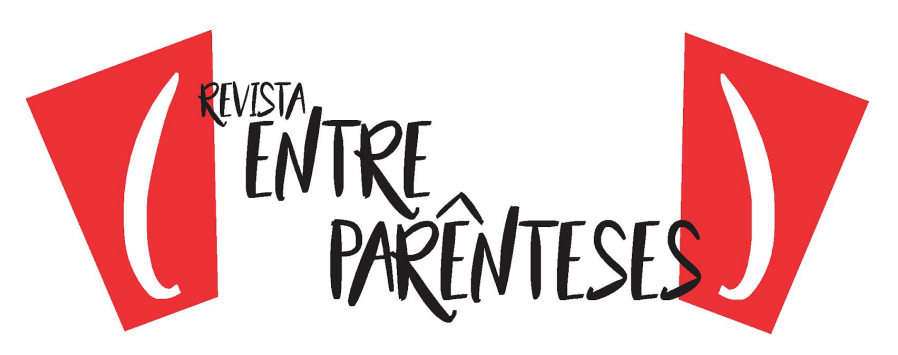

No começo dos anos de 1800, o estado de Minas Gerais começou a receber seus primeiros jornais, mesmo que nem todos tenham tido vida longa. Segundo a pesquisadora Aparecida Maria Nunes, em seu artigo $O$ olhar feminino sobre o Oitocentos na imprensa de Dona Francisca Senhorinha, a cidade de Campanha, no sul do estado, tornou-se um importante polo redatorial, contando com jornais como Colombo e $\mathbf{O}$ opinião campanhense, além de $\mathbf{O}$ Monarchista, editado por José Joaquim da Silva Diniz, esposo de Dona Francisca Senhorinha da Motta Diniz, a primeira mulher da cidade a comandar um jornal.

Nascida em São José del-Rei (atual Tiradentes), Minas Gerais, foi filha de Eduardo Gonçalves da Motta Ramos e Gertrudes Alves de Mello Ramos. Casou-se com o advogado, professor e editor José Joaquim da Silva Diniz, com quem teve três filhas: Amélia Augusta Diniz, Albertina Augusta Diniz e Elisa Diniz Machado Coelho. Foi, além de jornalista, professora primária e grande defensora do direito das mulheres à educação.

Com o apoio de seu marido, dono da tipografia, publicou, em sete de setembro de 1873 , o primeiro número de seu jornal feminino e feminista 0 sexo feminino, com o objetivo de instruir suas leitoras quanto a seus direitos e conquistar simpatizantes para a causa da luta das mulheres. Movida, assim como Nísia Floresta, pela percepção de que grande parte dos males da sociedade da época vinha do fato de negarem educação de qualidade às mulheres, prendendo-as em casa, Francisca Senhorinha fez combativas críticas aos governantes contemporâneos, denunciando a falta de oportunidades oferecidas ao sexo feminino e assumindo, assim, a vanguarda deste movimento no sul de Minas Gerais.

A jornalista e professora imaginou que sua iniciativa seria retaliada e zombada pelos homens da sociedade, mas, na verdade, recebeu grande apoio e incentivos para que continuasse em sua empreitada. Foi bem recebida por jornalistas e escritores, além de cativar um fiel público que fez com que o número de cópias impressas fosse cada vez maior, como relata Aparecida Maria Nunes. 


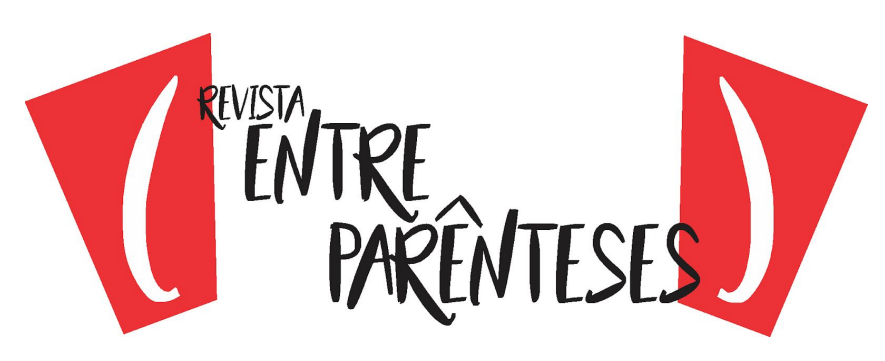

Francisca Senhorinha contou ainda com D. Pedro II como seu leitor, além de ter sua folha exportada para leitores da Europa e Estados Unidos.

Usando o semanário como ferramenta para a construção e difusão de um discurso, Francisca convidou as mulheres a utilizarem-se da pena, incentivando-as a divulgarem suas produções. Assim, em suas páginas, algumas colaboradoras tiveram grande destaque publicando poemas, artigos e traduções. Suas filhas Albertina e Amélia também traduziram, algumas vezes, obras literárias francesas para serem publicadas na folha.

Com a leitura das páginas d'O sexo feminino, percebe-se que sua mais constante e engajada contribuinte, colaborando com artigos e poemas para o jornal de Francisca Senhorinha, foi a poetisa Narcisa Amália de Campos, republicana, grande ativista pelos direitos da mulher e pela abolição da escravatura, cujos textos mostram-se portas de acesso para a melhor compreensão da organização feminina em prol dos direitos humanos nos jornais do Oitocentos.

\section{Narcisa Amália: a pena ágil}

Conhecida por sua "pena ágil", Narcisa Amália nasceu em São João da Barra, Rio de Janeiro, no dia 3 de abril de 1852. Além de poetisa, foi jornalista e professora, e privilegiava muito a função social de sua poesia. Escreveu durante o período de crise da monarquia no Brasil e usava temas recorrentes entre os intelectuais da época, como a abolição da escravatura e a proclamação da república, além de falar sobre a participação que o povo deveria ter no progresso.

Seu pai, o professor Jácome de Campos, era grande intelectual local e também poeta, sendo "um dos fundadores e principais redatores do primeiro jornal editado em São João da Barra: O Parahybano" (OSCAR, 1994, p. 19), o que ajuda a entender a precoce relação de Narcisa Amália com as letras em geral. Sua mãe, a 


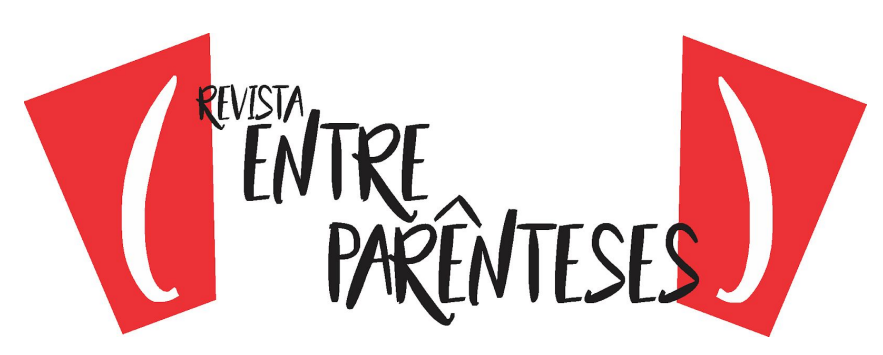

portuguesa Narcisa Ignácia Pereira de Mendonça, também era professora, atuando na rede pública primária.

Em 14 de julho de 1863, sua família se mudou de São João da Barra rumo ao clima serrano de Resende, no sul do Rio de Janeiro, devido a problemas respiratórios do patriarca. É lá que Narcisa Amália iria se firmar enquanto jornalista e escritora, além de ativista abolicionista e defensora dos direitos das mulheres.

Aos quatorze anos, foi obrigada a casar-se com João Batista da Silveira, que contava pouco mais de dezoito anos, devido a um escândalo familiar. Pouco mais de quatro anos depois, entretanto, o casamento acabou, e foi desses imensos sentimentos de tristeza e decepção que a poetisa retirou sua inspiração para a composição de poemas.

A poesia, desde o começo, apareceu para Narcisa como escape dos infelizes momentos que estava vivendo, sendo uma fuga da realidade. Como Antônio Simões dos Reis afirma, logo nas primeiras páginas de sua Bibliografia Brasileira: Narcisa Amália:

E no seu sonho para o mundo não se reviu o seu sonho para si. Nas letras foi verdadeira deusa, em prosa e verso cantada, com exaltação, por tudo quanto houve de mais representativo na época. No amor, desses amores incompreensíveis, amargou os estilhaços de uma aventura não atingida. A artista aureolada não conseguira ser deusa no próprio lar. ${ }^{3}$ (REIS, 1949, p. 15).

Narcisa Amália começou a ganhar espaço na imprensa traduzindo contos e ensaios do francês para o português e passando, em seguida, a publicar os próprios poemas em jornais como o Astro Resendense, Monitor Campista e Correio Fluminense. Em 1872, seu livro de poemas intitulado Nebulosas foi publicado, causando impacto na cena literária da época. É considerada por João Oscar, pesquisador que também se propôs a organizar a biografia da poetisa, com

\footnotetext{
${ }^{3}$ Ortografia atualizada.
} 


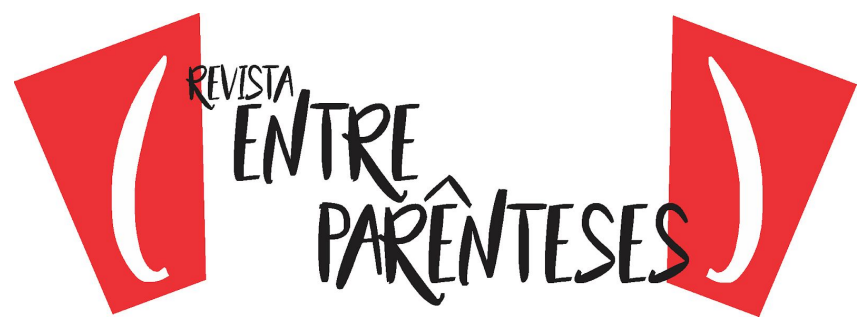

Narcisa Amália - vida e poesia, "a primeira mulher-escritora brasileira a conquistar espaço no fechadíssimo cenário literário do País." (OSCAR, 1994, p. 32).

Em seus poemas, a jovem escritora denunciava e indignava-se com as injustiças sociais, principalmente as cometidas contra os escravos. Crescida em lar abolicionista, desde pequena possuía consciência do quão desumana era a situação dos negros no Brasil, fato que ela constatava nas fazendas da redondeza. Esse cenário político-social refletiu-se em seus escritos, cheios de paixão e vontade de mudança; é apontada, ainda por João Oscar, como a "primeira poetisa social do Brasil" (OSCAR, 1994, p. 59).

Por conta dessas provocações, aliadas ao fato de Narcisa ser mulher em campo totalmente masculino, algumas personalidades da época debocharam de sua capacidade, considerando seus versos "choramingos" e afirmando que uma moça como ela não deveria se aventurar por assuntos que cabiam aos homens. Mas, em número superior a estes, haviam escritores e intelectuais que aprovaram seu trabalho, fazendo com que as Nebulosas obtivessem ótimas críticas e divulgação, servindo de exemplo e inspiração para a luta abolicionista, republicana e, principalmente, da emancipação das mulheres.

Como jornalista, Narcisa Amália também ocupou papel de vanguarda. João Oscar afirma categoricamente que:

Ainda que Violante Atabaliba Ximenes de Bivar, com o Jornal das Senhoras, de Salvador, seja "tida como a primeira brasileira a fazer e ter jornal" (...), cabe a Narcisa Amália, de acordo com grande parte dos que se detiveram a pesquisar as origens da imprensa nacional, a primazia de ter sido a primeira mulher a figurar como jornalista profissional e a ganhar projeção em todo o Brasil. Seus trabalhos na imprensa, amplamente conhecidos e diversificados nas páginas dos mais importantes jornais do País, assim o atestam. (OSCAR, 1994, p. 54).

O jornal, para Narcisa, era espaço de militância, um megafone pelo qual as injustiças daquela sociedade poderiam ser gritadas nas faces de quem as cometia. Ela via n'O sexo feminino de Francisca Senhorinha importante ferramenta 


\section{("twing}

de divulgação das pautas que defendia, como percebe-se no excerto a seguir, retirado na publicação de 11 de outubro de 1873 da folha:

A educação moral e a instrução intelectual da mulher, que em todos os tempos e em todos os países têm sido encaradas com o mais solene desprezo, vão surgir entre nós animadas pelo Sexo Feminino, que, na atualidade, parece ser o único meio que possuímos de despertá-las, levando-nos à suprema perfectibilidade de que somos susceptíveis - meta inatingível talvez; - polo único e sempre atraente de todas as grandes aspirações da humanidade. (CAMPOS, O sexo feminino, 1873, p. 2).

A influência e fama de Narcisa foram tão grandes no meio em que estava inserida que chegou a ser visitada duas vezes pelo próprio D. Pedro II - a primeira em 1874, a segunda em 1886 - impelido pelo desejo de conhecer a tão aclamada autora das Nebulosas. Ela seguiu, persistentemente, publicando novos poemas e alguns trabalhos em prosa em diversos jornais de circulação nas capitais e interiores.

Em 1880, devido às dificuldades financeiras de sua família decorrentes da morte do patriarca Jácome de Campos, Narcisa Amália realizou seu segundo matrimônio, desta vez com o padeiro português Francisco Cleto da Rocha. Narcisa, solicitamente, passou a ajudá-lo na padaria, deixando sua produção literária de lado. Querida e popular, continuou recebendo muitas visitas de poetas e amigos em pequenos saraus, como Raimundo Correia e Luís Murat, o que despertava os ciúmes e impaciências do esposo, que não acompanhava ou interessava-se por conversas literárias, vendo a mulher sempre tão intelectualmente disputada, inclusive por D. Pedro II.

Assim, devido à intolerância do marido, separaram-se em 1887, depois de muito sofrimento e tentativas de reconciliação por parte da poetisa, que se rebelou após ser proibida por ele de receber suas visitas. Não aceitando a situação e a humilhação de perder a esposa, Francisco da Rocha começou a difamá-la nos

\footnotetext{
${ }^{4}$ Todos os trechos retirados do jornal $\mathbf{O}$ sexo feminino tiveram sua ortografia atualizada para melhor compreensão do texto.
} 


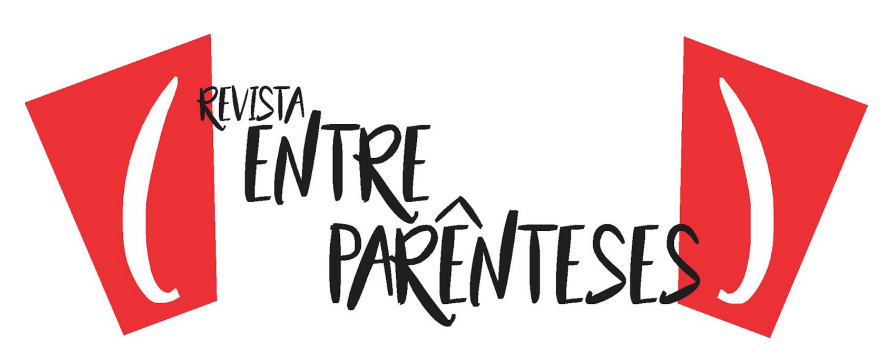

meios em que viviam, dizendo, até mesmo, que ela não era a legítima autora de seus versos e, sim, que os copiava de outros poetas (com os quais, segundo ele, Narcisa teria relações amorosas), clamando-os como seus. Os contemporâneos de Francisco da Rocha, no entanto, não acreditaram na história, claramente inventada por um marido despeitado.

Narcisa, então, profundamente abalada e magoada com os boatos, mudou-se de Resende para o Rio de Janeiro, e nunca mais retornaria à cidade que tão bem a recebeu, mas que tamanha decepção acabou proporcionando-lhe. $\mathrm{Na}$ Corte, estabeleceu-se enquanto professora e recebeu grandes elogios por seu desempenho no campo da educação. Lentamente, dessa maneira, Narcisa foi-se separando dos movimentos literários e focando-se no ensino que, afinal, sempre foi uma de suas maiores pautas.

\section{Jornalismo como resistência}

A participação de Narcisa Amália em 0 sexo feminino não se limitou a poemas publicados na folha, mas também contou com interessantes artigos sobre a instrução feminina. Como comenta a professora Aparecida Maria Nunes em seu artigo já citado, "[...] Narcisa se une a Francisca na luta que vê na imprensa feminina uma sociedade melhor." (NUNES, 2014, p. 103). Narcisa apoiou O sexo feminino até seu encerramento, enviando com frequência poemas para publicação, mesmo que esses falassem de temas menos polêmicos para a época, como o amor. A seguir, pretende-se observar algumas das contribuições da escritora para o jornal campanhense.

Com grande entusiasmo, Francisca Senhorinha recebeu a aclamada poetisa a sua folha, como se nota no seguinte trecho publicado na edição de 11 de outubro de 1873:

AOS NOSSOS ASSINANTES, UMA GRATA NOTÍCIA - Este periódico tem o indizivel prazer de cientificar aos seus leitores que 


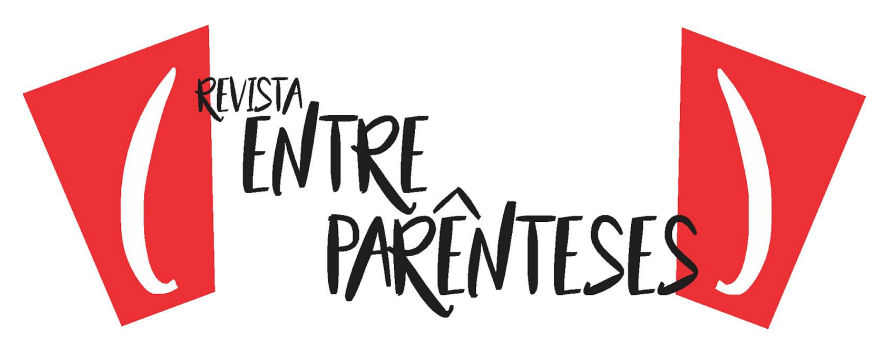

vai enumerar como colaboradora uma das penas mais hábeis que tem aparecido na imprensa diária da corte. A Ex. ${ }^{a}$ Sr. $^{a}$ D. Narcisa Amália, poetisa distinta, literata não vulgar, talento transcendental, está acima de qualquer elogio que a pena mais bem aparada possa tecer. Sua áurea inteligência se desenha no artigo com que mimoseou $\mathbf{O}$ Sexo Feminino, e que vai publicado no lugar competente.

Chamamos para ele a atenção não somente do nosso sexo, mais ainda do orgulhoso sexo contrário, e muito principalmente dos retrógrados e pessimistas que não creem que as mulheres possam ser escritoras. (DINIZ, O sexo feminino, 1873, p. 4, grifos da autora).

Francisca Senhorinha desafia os homens de sua época a atentarem-se aos textos de Narcisa, porque vê neles provas de que uma mulher poderia escrever, e com maestria.

A jornalista prestou à Narcisa públicos e intensos agradecimentos por apostar em sua iniciativa e colaborar para a evolução intelectual das mulheres brasileiras, como se vê no artigo publicado em $1^{\circ}$ de novembro de 1873 , com o título de Narcisa Amália:

À brilhante e distinta escritora e poetisa; à romeira na espinhosa peregrinação do jornalismo; à nossa amiga finalmente, vimos nós hoje colaboradoras do Sexo Feminino, em fraternal abraço, pagar o tributo de admiração que lhe rendemos: é a expansão de um afeto d'alma.

Quem depois de compulsar as ricas produção da pena de Narcisa Amália; quem depois de ler as sublimes - Nebulosas - não pronunciará com entusiasmo e admiração o seu nome?!

Entusiasmo sim, esse fogo que segundo a frase de um escritor contemporâneo, se ateia em chamas dentro dos corações; e admiração mais que tudo, à heroína brasileira, que desprendendo-se do comum do nosso sexo, qual águia altiva, abre o voo à imaginação e pairando em regiões ignotas onde a leva sua varonil inteligência, vai semeando torrentes de flores que o mundo colhe e admira! (DINIZ, O sexo feminino, 1873, p.3).

Nota-se, no excerto acima, como Francisca Senhorinha, atrelada à visão vigente de sua época, disse que Narcisa Amália desprende-se do que é comum às mulheres e alça novos voos; utilizou, para qualificá-la, o adjetivo "varonil", 


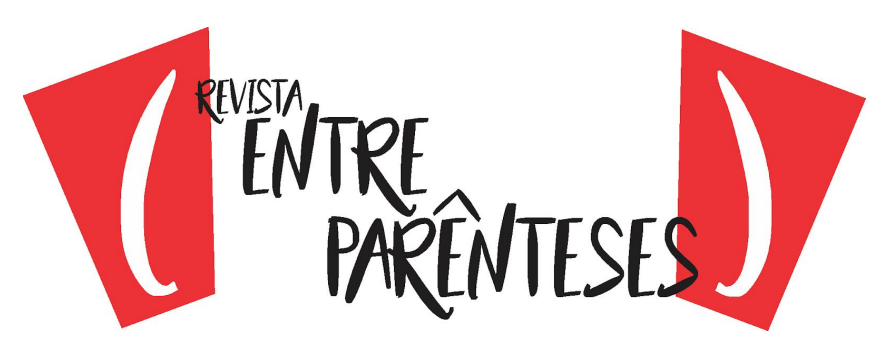

associando a inteligência ao sexo masculino. Francisca Senhorinha complementa sua ideia afirmando que por meio dos papéis, dos livros e da intelectualidade, as mulheres conseguiriam abrir seu espaço e contribuir para o avanço da nação:

Que coração brasileiro há por aí tão gélido ou estoico, que não se sinta orgulhosamente inflamado ao pronunciar o nome de Narcisa Amália?! [...] Surgem as Narcisas Amálias; surgem as mulheres, esquecidas, desprezadas e aviltadas até aqui, cujas produções vão amontoando material para a edificação de monumentos, não de pedra ou bronze, mas de papel, de livros, de doutrinas morais que os séculos presentes e futuros glorificarão com entusiasmo e admiração. (DINIZ, O sexo feminino, 1873, p. 3).

Senhorinha, em tom de manifesto, convocou suas leitoras a utilizarem as palavras e as penas como meio de ascensão e de luta pelos direitos a elas negados:

Narcisa Amália! Fomos há pouco mimoseadas com um primoroso artigo, fruto de vossa ilustração e com que foram honradas as colunas do Sexo Feminino; agradecendo-vos, pedimos a continuação de vosso valioso contingente para que desempenhemos cabalmente a tarefas que nos impusemos.

Em nossa peregrinação, arrancando cotidianamente os espinhos que nos dilaceram as carnes, caminharemos tanto quanto as nossas débeis forças o permitam. Noveis nas lides da imprensa, se nos faltam as armas da inteligência, sobra-nos o patriotismo, a decidida vontade e propósito de arrancar o nosso sexo das garras do tirano que tenta tê-lo perpetuamente sob sua feudal dominação.

Sim, Narcisa Amália! trabalhemos todas, cada mulher seja um obreiro, com a palavra, com a pena, e com todos os dados que se nos oferecer conquistemos nossos direitos postergados, porque a vitória será nossa. (DINIZ, O sexo feminino, 1873, p. 3).

A jornalista (não se sabe se em tom irônico ou não) novamente atribuiu aos homens o "dom" da inteligência, ao questionar se "faltam as armas da inteligência" às mulheres; entretanto, delegou ao sexo feminino força de vontade, patriotismo e determinação para libertarem-se das amarras patriarcais e feudais nas quais se encontravam.

Importantes opiniões acerca da educação das mulheres e do papel que deveria ocupar na sociedade foram escritas por Narcisa Amália no artigo intitulado A 


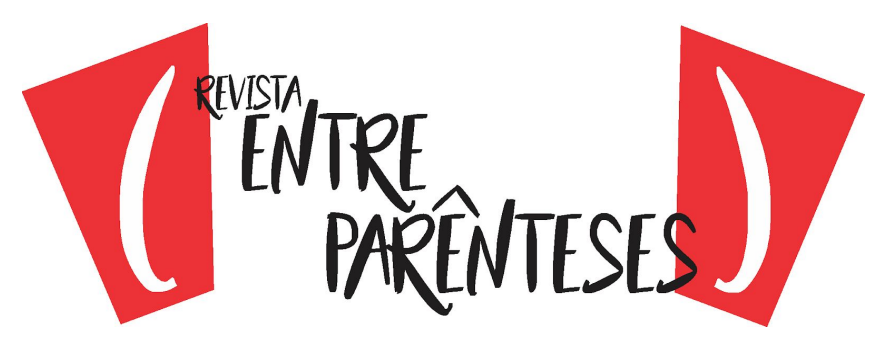

nossa instrução, em 25 de setembro de 1873 e publicado no número de 11 de outubro de 1873, reproduzido integralmente abaixo e repartido para melhor análise. É um dos mais contundentes escritos de Narcisa Amália em favor da instrução intelectual das mulheres, verdadeiro manifesto no qual discorreu sobre a situação em que se encontrava o sexo feminino, ao mesmo tempo em que intimou as e os campanhenses e demais cidadãos para juntarem-se à causa:

A educação moral e a instrução intelectual da mulher, que em todos os tempos e em todos os países têm sido encaradas com o mais solene desprezo, vão surgir entre nós animadas pelo Sexo Feminino, que, na atualidade, parece ser o único meio que possuímos de despertá-las, levando-nos à suprema perfectibilidade de que somos susceptíveis - meta inatingível talvez; - polo único e sempre atraente de todas as grandes aspirações da humanidade.

Homens inteligentes, grandes notabilidades mesmo, cerrando os olhos ao majestoso espetáculo que ao mundo oferece a América do Norte, o primeiro país que ousou dignificar e elevar a conveniente altura a mais nobre e abatida metade do gênero humano, insistem em que a razão não pode imperar no sexo feminil, por que o predomínio absoluto do sentimento nulifica-o para tudo.

Que a mulher recebeu da natureza o mimo da sensibilidade, é uma verdade indiscutível; porém essa verdade clama bem alto a favor de suas aptidões intelectuais.

Assim como o sol reanima e desenvolve certos organismos débeis, comunicando-Ihes um pouco de calor às fibras enervadas; assim também o sentimento desperta o amor do belo e a sede de luz nos seres habituados às trevas e ao erro, pois existe uma electricidade moral que nele tem o mais favorável dos condutores. Essa faculdade, fraca e transitória no homem, adquire na mulher poderosa estabilidade; ela é, por assim dizer, o óleo que alimenta no santuário recondito da alma a chama sagrada do entusiasmo, e sem o entusiasmo as mais sublimes dedicações se resfriariam. (CAMPOS, O sexo feminino, 1873, p. 2).

Mantendo-se, em alguns pontos, fiel ao pensamento da época, Narcisa tratou sobre a sensibilidade feminina, mas imediatamente distoou ao dizer que essa qualidade deveria ser usada juntamente à intelectualidade, o que faria as mulheres se destacarem nos trabalhos que se dispusessem a fazer. 


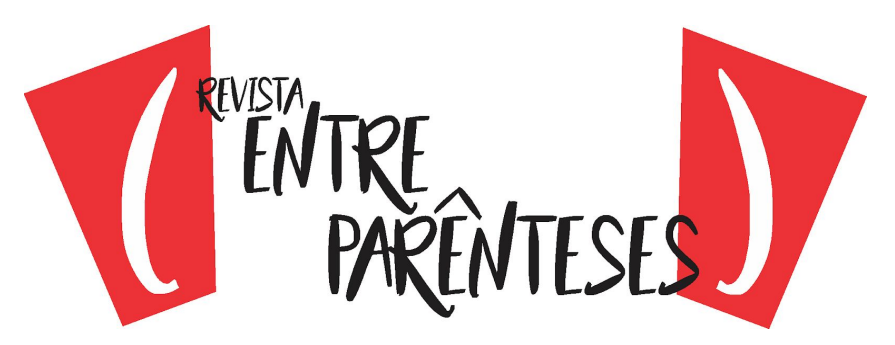

Educada como está, a mulher não passa de uma linda orquídea que busca um apoio, e elada a ele vegeta sem consciência da própria existência.

Sempre encastelada n'um idealismo crônico, ela contempla de longe a sociedade pelo falso prisma que a sua imaginação romanesca lhe apresenta; mas quando as necessidades afugentam o ideal, e, gasta a alfombra de gozos, ela imprime a planta delicada nas escabrosidades da vida real, como a sensitiva a estranho contato, cai fulminada, pois em vez de faculdades desenvolvidas e aproveitáveis só deram-lhe nervos que se irritam à mais ligeira contrariedade.

Assim vive, e assim morre, sempre ignorando que é no seu cérebro ocioso, que é no seu espírito caprichoso e frívolo que repousam os gérmens desse bem estar social que o povo em vão implora às leis e aos governos que nos regem. Eduque a sociedade convenientemente essa criaturinha sensível e meiga; individualize-a, dando-lhe a responsabilidade moral de seus atos, e a sua propaganda redentora será eficaz. (CAMPOS, O sexo feminino, 1873, p. 2-3).

No trecho acima, Narcisa comparou o destino das mulheres da época, entendidas como parasitas à sombra dos maridos, com o futuro das mulheres instruídas, conscientes de quem são e preocupadas com o progresso de sua nação. Evidencia-se uma ideia recorrente: só pela liberdade da mulher é que a justiça e avanço do país serão alcançados. Assim, a educação e empoderamento feminino não interessam somente às mulheres, mas sim a todos que se preocupam com o futuro da nação.

Influa o seu espírito sequioso com os princípios fecundantes da ciência, e de cada lábio voará um poema de verdades. Torne-a uma mãe que possa ensinar filosoficamente o bem a seus filhos, e será resolvido o problema da libertação dos povos, libertação baseada na instrução, na moralidade e no trabalho. (CAMPOS, O sexo feminino, 1873, p. 3).

A educação ajudaria, ainda, essas mulheres a serem melhores mães e donas de casa, conscientes das dinâmicas que as envolvem e capazes de educar "filosoficamente" seus filhos. No trecho a seguir, a poetisa saudou as campanhenses, na figura predominante de Francisca Senhorinha, por ousarem 


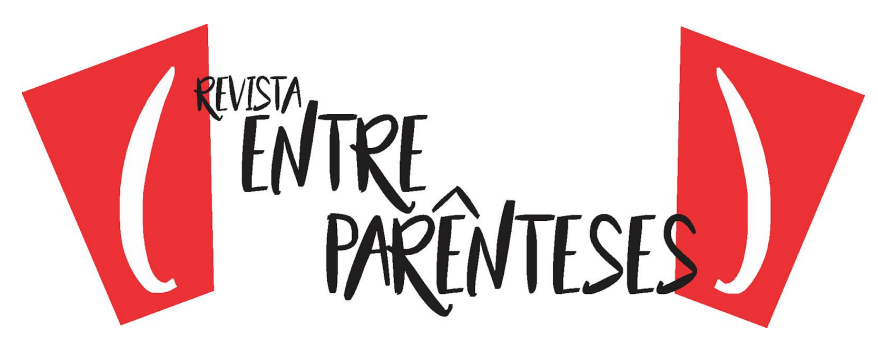

construir o jornal e colocarem-se contra o pensamento predominante da sociedade da época, chamando a todos para aliarem-se à causa das mulheres:

Honra e respeito nacional a vós, distintas campanhenses, que não hesitastes em dar o primeiro passo para a redenção do nosso deprimido sexo.

Do seio dessa terra de Minas, tão rica de seiva e de juventude; do seio dessa terra generosa que recebeu e fecundou as primeiras idéas da nossa emancipação politica, é que devia tambem partir o primeiro brado pela emancipação da mulher.

Berço diamantino das glórias nacionais; Salve! (CAMPOS, O sexo feminino, 1873, p. 3).

Nesse sentido, é interessante, também, notar a carta aberta dividida em duas partes que a poetisa publicou ao advogado Miguel Vieira Ferreira, ativista abolicionista e simpatizante das causas feministas, publicada nos volumes de 29 de novembro e seis de dezembro de 1873.

Presentemente, que individualidade representamos nós? Ou antes: que tipo social encarna com perfeição a mulher brasileira?...

Como filha, - possue ela essa candura imaculada que faz da virgem um anjo da terra, unida ao conhecimento exato da sociedade em que vive, conhecimento que a sua segurança pessoal exige?...

- Não; porque o contato da escravidão basta para ensombrar desde cedo a brancura ideal de suas asas, e a educação que recebem ensina-a a encarar a sociedade sob um aspecto muito diverso do que nela descobre o olhar profundo e reflexivo do pensador.

Como esposa, - tem por seu esposo a dedicação sem limites que exige o enlace cristão? Dedica-lhe essa estima pura e respeitosa que deve ligar intimamente dois indivíduos que empreendem juntos uma viagem através do deserto e que tem de descansar no fim do dia à sombra piedosa da mesma palmeira?... (CAMPOS, O sexo feminino, 1873 , p. 3).

Narcisa Amália, nessa carta, subverteu a ideia da mulher como anjo imaculado na Terra, usando para isso o contraposto com a escravidão, a falta de uma educação reflexiva para as mulheres e o casamento como instituição que não cumpre com seu objetivo - o companheirismo e respeito mútuos. Nota-se, acima, a 


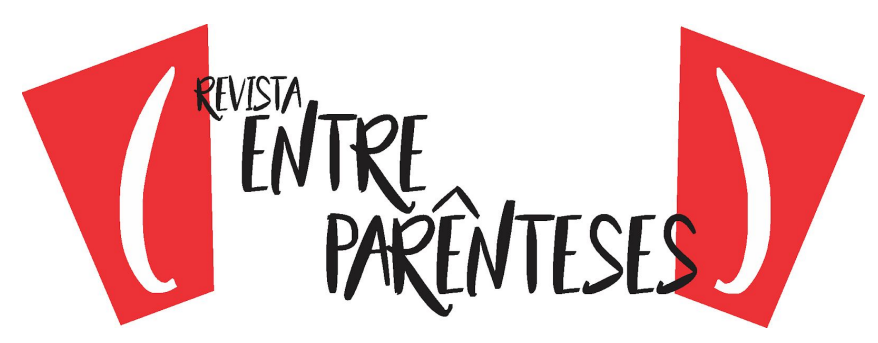

influência que o contato precoce com a escravidão nas fazendas próximas a sua casa teve em seu pensamento e em seus escritos.

Continuando seu raciocínio, a escritora fez dura crítica à instituição do casamento, que subjuga a mulher, escravizando-a e diminuindo-a:

- Não; porque desconhecendo inteiramente o caráter do indivíduo a quem se alia, vai, muitas vezes, encontrar a desgraça nessa união santificada que devera assegurar-lhe a felicidade na vida; porque 0 marido, não a considerando como a colaboradora afetuosa de sua existência, trata-a como uma escrava, curva e resignada à sua caprichosa prepotência, e a escrava, de dia para dia, sente tornar-se mais odiosa essa tirania autorizada pelos costumes. (CAMPOS, $O$ sexo feminino, 1873, p. 3).

Narcisa Amália afirmou que somente pela instrução intelectual das mulheres poderia haver justiça e progresso no país para todos; disse, também, que a mulher precisaria entender-se enquanto capaz e igual para, com confiança, lutar por seus direitos e conduzir o país ao progresso.

Quando a sua individualidade for reconstituída perante os homens, e, especialmente, perante a sua própria consciência; quando se lhe outorgar o direito de ilustrar-se e de viver racionalmente, esta mulher brasileira tão ignorante e tão opulenta de inteligência; tão supersticiosa e tão amante da caridade; tão vilipendiada e tão cheia de dignidade e abnegação, saberá cumprir gloriosamente a augusta missão de que está encarregada: - a de conduzir este escravizado país às raias de perfeição suprema. (CAMPOS, $\mathbf{0}$ sexo feminino, 1873, p. 2).

Caberia, portanto, às mulheres, armadas com a educação, inteligência e usando como porta-voz os jornais e a literatura, abrir o caminho para a plena liberdade e para o progresso intelectual do Brasil.

\section{Considerações finais}




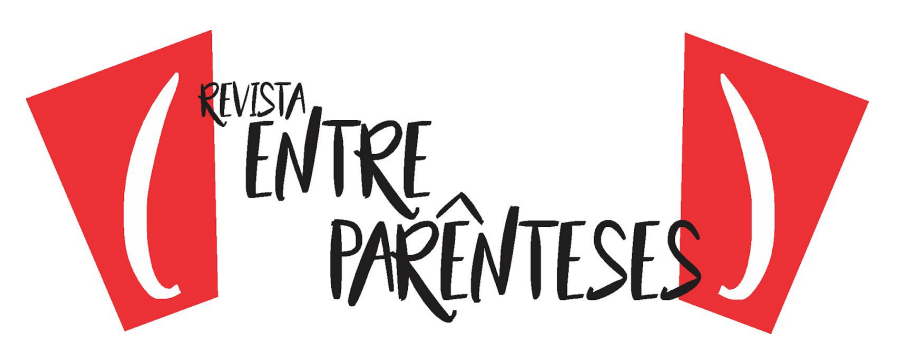

A história de nosso país está permeada de momentos de rebeldia e subversão, mas nem todos são contados, expostos e estudados pelo cânone literário. Grande parte desses momentos soterrados foi protagonizada por mulheres que não se sujeitaram apenas aos papéis que Ihes cabiam na época em que viveram. Essas mulheres ousaram escrever, reivindicar e refletir sobre as injustiças sociais que permeavam as relações ao seu entorno.

Narcisa Amália de Campos e Francisca Senhorinha da Motta Diniz foram exemplos dessa coragem e desobediência aos costumes vigentes. Impuseram-se enquanto mulheres que exigiam serem tratadas como iguais, que queriam a possibilidade de trabalhar, escrever, ler e exercer suas cidadanias, pagando, algumas vezes, o preço por esses desejos, como Narcisa Amália, que foi caluniada por seu ex esposo.

É preciso retomar as reflexões dessas mulheres, que mostram uma visão crítica da sociedade do Oitocentos que não está no cânone. É por meio da literatura e do jornalismo que encontramos retratos da real sociedade que não estão nos livros de História, tampouco são estudados na escola. Nos livros e nos jornais, estão as representações dos costumes da época, bem como da resistência contra eles. Infelizmente, muitos desses dados permanecem escondidos em arquivos empoeirados que não são explorados ou debatidos.

Este artigo se propôs a resgatar os discursos visionários da jornalista, educadora e poetisa Narcisa Amália e da também jornalista e educadora Francisca Senhorinha, ícones do jornalismo e do feminismo brasileiro em suas origens. Essas duas mulheres contribuíram na construção de novos caminhos para toda uma próxima geração de jornalistas, escritoras e professoras que viam na palavra escrita um modo de subverter as normas e reivindicar seus direitos.

A poesia de Narcisa Amália, além de bela, é social e engajada, trazendo suas visões de sociedades e as mudanças que dela se esperavam. Sua contribuição para a imprensa mostra a coragem de expor seu nome e suas ousadas opiniões, 


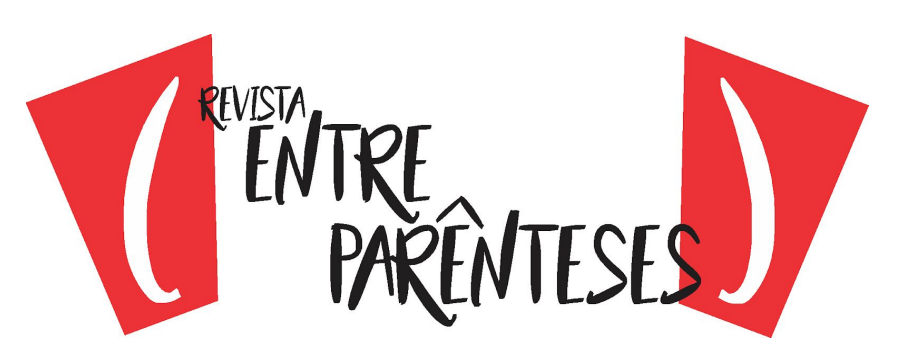

que viam na educação feminina a saída para o atraso que o Brasil enfrentava. Educando a todos seus cidadãos, sem exceção, a pátria avançaria sem deixar ninguém para trás.

Narcisa Amália é, ainda hoje, grandemente estimada pelo povo de São João da Barra, sendo homenageada com uma sala da câmara municipal da cidade que leva seu nome e com o lançamento financiado pela prefeitura do livro Narcisa Amália - vida e poesia, escrito e organizado por João Oscar e publicado em 1994. Mesmo que a poetisa tenha deixado a cidade com apenas onze anos, São João da Barra causou-lhe grande impressão e inspiração, que acompanhar-lhe-iam por toda a sua vida e carreira, fazendo-se presente em diversas passagens de poemas e textos em geral.

Os escritos de Narcisa deixados nas páginas d'O Sexo feminino são importantes documentos históricos que ajudam a montar o complexo quebra-cabeça das relações de poder que permeavam a sociedade do Oitocentos. Assim, o movimento de pesquisar o passado para se compreender melhor o presente mostra-se sempre válido, pois quanto maior a reflexão sobre as histórias (oficiais e, principalmente, não oficiais) do país, mais acurada é a visão e a autocrítica dos cidadãos sobre sua identidade e seu passado, rumo à construção de futuros mais igualitários.

\section{Referências}

BARBOSA, G. O. Aspectos sociais e políticos da poesia de Narcisa Amália. XXII Simpósio Nacional de História, p. 1-7, 2003.

FONSECA, Y. V. Narcisa Amália - 150 anos de nascimento. Rio de Janeiro: Academia Niteroiense de Letras, 2002.

NETO, R. D. T. Página pessoal. Rainhas trágicas. Transgressão feminina na imprensa brasileira: as jornalistas do século XIX. Disponível em: 


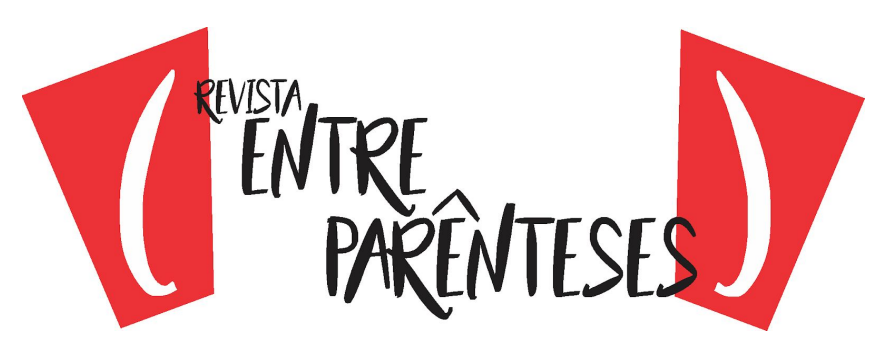

<https://rainhastragicas.com/2015/11/21/as-jornalistas-do-seculo-xix/>. Acesso em: 18 jan. 2020.

NUNES, A. M. O olhar feminino sobre o Oitocentos na imprensa de Dona Francisca Senhorinha. In: NUNES, A. M. et al. (orgs). Olhares cruzados: percursos interpretativos. Campinas: Pontes, 2014. p. 83-109.

O SEXO FEMININO. Brasil. Minas Gerais: Arquivo pessoal de Aparecida Maria Nunes.

OSCAR, J. Narcisa Amália, Vida e Poesia. Campos: Lar Cristão, 1994.

REIS, A. S. Bibliografia Brasileira: Narcisa Amália. Rio de Janeiro: Organizações Simões, 1949.

ROSA, G. T. A mulher projetada no discurso: a construção ethótica de Senhorinha Diniz em O Sexo Feminino. ContraPonto, Belo Horizonte, v. 1, n. 1, p. 126-143, jul.2011.

TELLES, N. Página pessoal. Norma Telles. Rebeldes, escritoras, abolicionistas. Disponível em <http://www.normatelles.com.br/Rebeldes-Escritoras-Abolicionistas.html>. Acesso em: 15 ago. 2017.

VASCONCELLOS, E., SAVELLI, I. M. A imprensa feminina. Verbo de Minas: letras, Juíz de Fora, p. 89-102, 2006.

Recebido em: 29/09/2019

Aceito em: 18/01/2020 